\title{
Independent Candidates in the Concurrent Regional Election in South Sulawesi: What is Independent and Why?
}

\author{
Rasyid Thaha ${ }^{1}$ \\ Haryanto ${ }^{2}$
}

\begin{abstract}
Researchers in many countries consider that independent candidates affect the quality of elections wherein independent candidates can enhance the consolidation of democracy within the context of political openness, bring about more competitive elections, and become an established pathway for alternative leadership figures. In Indonesia, these conclusions need to be further explored with the implementation of provisions regarding independent candidates in local elections. Therefore, the main objective of this research is to illustrate the political events involving each individual candidate based on questions of individual actions. The main questions relate to why candidates choose the path of an independent, what capital they have, why are independent candidates more influential than others, and what are the consequences of their presence for democracy in Indonesia. This paper concludes that the independent track is merely one of the means available, in addition to the party, in pursuing political office in local elections. There is no apparent footing relating to what independent candidates stand for. Moreover, there is yet to be an independent candidate who is truly a social activist wanting to promote alternative issues, a representative of interest groups, or a representative of classes in the local community. Independent candidates are a part of a Schumpeterian procedural logic which is merely for political elite circulation. To put it simply, there is nothing new and rejuvenating in the practices of local democracy in Indonesia.
\end{abstract}

\section{Keywords:}

independent candidate; pilkada; local politics; democracy.

\section{Abstrak}

Peneliti di banyak negara menganggap bahwa calon perseorangan memengaruhi kualitas pemilu di mana calon perseorangan dapat meningkatkan konsolidasi demokrasi dengan adanya keterbukaan politik, membawa pemilihan lebih kompetitif, dan menjadi jalur figur pemimpin alternatif. Di Indonesia, kesimpulan tersebut perlu untuk ditelusuri lebih lanjut dengan diterapkannya calon perseorangan dalam pemilihan kepala daerah. Untuk itu, tujuan utama dalam penelitian ini adalah menggambarkan berbagai peristiwa politik yang melibatkan masingmasing calon perseorangan berdasarkan pertanyaan-pertanyaan pada tindakan individu. Pertanyaan utama terkait dengan mengapa para calon memilih jalur perseorangan, modal apa yang mereka miliki, mengapa calon perseorangan lebih berpengaruh daripada yang lain, dan apa konsekuensi dari kehadiran calon perseorangan bagi demokrasi di Indonesia? Tulisan ini menyimpulkan bahwa memilih jalur perseorangan hanyalah salah satu jalur disamping jalur partai untuk mengejar jabatan politik di pemilihan kepala daerah. Tidak ada basis yang jelas terkait apa yang calon perseorangan perjuangkan. Selain itu, belum ada calon perseorangan yang benar-benar merupakan aktivis masyarakat yang ingin mempromosikan isu-isu alternatif, wakil dari kelompok kepentingan, atau perwakilan dari kelas-kelas di masyarakat lokal. Singkatnya, calon perseorangan adalah bagian dari logika prosedural Scumpetarian untuk sirkulasi elit politik semata. Tidak ada yang baru dan membarukan praktik demokrasi lokal di Indonesia.

\footnotetext{
1 Department of Politics and Government Sciences, Universitas Hasanuddin. Email: rasyid_thaha@yahoo.com.

2 Department of Politics and Government Sciences, Universitas Hasanuddin.
} 


\section{Kata Kunci:}

calon perseorangan; pilkada; politik lokal; demokrasi.

\section{Introduction}

Basically, the advent of independent candidates is a common phenomenon in various electoral systems of many countries, whether it is in an established democratic system or in one undergoing the process of democratic consolidation (Brancati, 2008; Ehin and Solvak, 2012), or even in an authoritarian system (Junzhi, 2010). Studies in relation to democracies with independent candidates in elections also vary. A number of researchers consider independent candidates influence election quality through such issues as election system, election participation, and deparpolisasi (the weakening of political parties) or anti-political party sentiments (Moser, 1999; Schaffner et al., 2001; Brancati, 2008). Meanwhile, other researchers show that independent candidates can increase consolidation of democracy by presenting political openness and bringing about more competitive elections as well as reducing the number of non-voters (Costar and Curtin, 2004; Junzhi, 2010). Independent candidates also have the potential to present a constructive pattern of political party competition which could on the contrary also lead to destructive ends (Ehin and Solvak, 2012; Ishiyama et al., 2011). In addition, the emergence of independent candidates is considered to be afforded to the weakness of prevailing political parties to accommodate community interests or is regarded as a failure in partisan democracy (Hale, 2007; Bolleyer and Weeks, 2009). Independent candidates are also acknowledged and practiced in the People's Republic of China (PRC) which implements a single party authoritarian regime. Although oppositional parties at the national level other than the Communist Party of China (CPC) are not eligible, independents are allowed to be involved in direct elections in the local community congress election system in PRC
(Junzhi, 2010). Several journalists and scientists in the communist country even predicted that the rise of independents in 2003 means new hope for democracy in China (Junzhi, 2010: 312).

Even though quite a lot of research have been conducted regarding independent candidates, it is difficult to find answers concerning the rise of independents at the micro level. The researches mentioned above mostly provide observations at the macro level referring to election systems and democratic institutions. In Indonesia, research on independent candidates remains limited. Although, in reality, the emergence of independent candidates in Indonesia dates back to the 1955 General Election as stipulated in Law No. 7 Year 1953 which accommodated independents contesting for seats in the Constituency and the People's Representative Assembly (DPR) with a number of requirements regarding voters' support. The result of the 1955 General Election also showed the presence of independent candidates that were successfully elected. In the post New Order General Election of 2004, independent candidates were also directly elected through the use of a bicameral system in the Regional Representative Council (DPD). At the local level, regulations regarding independent candidates have been around since 2006 particularly for Aceh, and it was subsequently accommodated throughout all the regions in Indonesia in 2008. Most of the available research provides observations that are based more on the perspective of constitutional law (Arbas et al., 2015; Martini et al., 2013) and general election system regulations (Nuryanti, 2015). Ultimately, conclusions referring to the relation of independent candidates, political behavior, and democracy in Indonesia have yet to find an enlightening explanation. Even 
more so at the local level with the existence of concurrent direct election for regional leaders.

The phenomenon in which independent candidates have a lot of involvement in Indonesia is indeed becoming more interesting for research, particularly following the election for regional leaders (pemilu kepala daerahpilkada) at the local level which has been stipulated to be conducted concurrently since 2015. Out of the 264 pilkada conducted in the regions (regencies, municipalities, and provinces), 35.5 percent of candidates running were from the independent track. As a result, 13 pairs of independent candidates successfully won or 14.4 percent were successfully elected (KPU, 2015). This is arguably the reason why political parties in Indonesia are becoming more conscious of independent candidates' presence. This is rightly proven with the change in regulation by increasing the number of requirements for independent candidates through Law No. 10 Year 2016. This reality begs the question of what is actually happening in the practice of pilkada politics in a country undergoing democratic consolidation of its political system and the political behavior of its citizens.

For that reason, this paper will analyze the advent of independent candidates with a number of the following main questions: why did candidates choose the independent track; what capital do they possess; why do some candidates have more influence -successful in winning the election-than others; and what are the consequences of their presence. Based on these questions, the study will thoroughly analyze each of the independent candidate pairs participating in the concurrent regional election held in South Sulawesi in 2015. The case of South Sulawesi is interesting to analyze as it demonstrates quite a complex polarization of independent candidate profiles in which party members, bureaucrats, and entrepreneurs were found to compete. This paper will illustrate various political occurrences which involved each independent candidate based on the questions presented above. Based on that analysis this paper attempts to find the political essence of independent candidates in the electoral system in Indonesia including its impact in institutionalizing democracy at the local level.

\section{Research Methodology}

This article is a result of a qualitative research which utilized a case study method and was conducted from August 2016 to October 2016. This research analyzed the experiences of independent candidates in South Sulawesi, hence the data and analysis presented refer to cases occurring in that region. The research object is specifically the individuals and their behaviors-albeit not through a psychological perspective-regarding interests, knowledge, and strategies in the regional election. Data collection was conducted through in-depth interviews of three independent candidates, one from the Pangkajene Kepulauan (Pangkep) Regency, one from the Gowa Regency, and another from the Bulukumba Regency. Other primary data were acquired from a number of key informants chosen based on their knowledge regarding the object of research. Secondary data were obtained from various sources of information such as the news, media, as well as documents from the General Election Commission (Komisi Pemilihan Umum- KPU).

Independent candidate in this research is defined as political actor utilizing the nonpartisan (non-affiliation to political party) path to achieve regional head candidacy. Regarding independent candidates, political researchers, particularly election, theoretically emphasizes the concept of nonpartisan or independence, a political elite which has no affiliation to any political party whatsoever (Ehin and Solvak, 2012; Ishiyama et al., 2011; Bolleyer et al., 2009; Weeks, 2008). This means that conceptually an independent candidate is an 
independent political actor who does not come from a political party and works independently for the interest of one's electorates. In Indonesia, the use of the word individual (perseorangan) for candidates is more or less the same with the use of the word independent in other research, particularly in foreign literature. The term individual candidate refers to the official terminology of the election system in Indonesia. Although, the Pilkada regulation (Law No. 10/2016) actually only stipulates that individual candidates are regional head candidates supported by a number of people, or a candidacy track mechanism undertaken outside of political parties.

\section{Independent Candidates in Legal Formal Analysis}

Since the fall of Soeharto in 1998 which was signified with the transformation of several regulations advocating the spirit of reform, Indonesia began its democratization process in various aspects of the political system. The National Constitution even experienced as much as four amendments. Several constitutional regulations became more democratic and decentralized all the way to the lowest regional level. Various electoral rules were also established to develop and support the idea of democracy. Elections at the local level in the past employed a representation system, which since 2005 was subsequently changed into a system of direct regional head election. The dynamics of the political system duly continued to the point that independent candidates outside the existing political parties were allowed to participate in the election of regional head.

The second amendment to Law No. 32 Year 2004 stipulated in Law No. 12 Year 2008 is the legal basis that accommodates independent candidates in the implementation of regional head election in Indonesia. ${ }^{3}$ However, allowing

3 This regulation came into being after undergoing the process of judicial review on Law No. 32 Year 2004 independent candidates to participate in regional head election had actually been done in the Aceh Province in 2006 based on the special autonomy rights retained by this region. ${ }^{4}$ The basic argument in allowing independent candidates to participate began from a judicial review result of the Constitutional Court in 2007 which among others concluded that certain articles in Law No. 32 Year 2004 on Regional Government limit the political rights of every citizen which are guaranteed in the 1945 Constitution of the Republic of Indonesia (UUD 1945). Hence, it is not uncommon that participation through other mechanisms outside political parties to engage in democracy be opened, which consequently provides the opportunity for independent candidates to run in the election for regional head and vicehead. ${ }^{5}$

Provisions regarding independent candidates in the regional head election system in Indonesia underwent several changes. Initially, the legal umbrella for independent candidates was stipulated in Law No. 12 Year 2008 which was then amended with Law No. 22 Year 2014. The following year, Law No. 22 Year 2014 was amended with Law No. 1 Year 2015 after quite a lengthy polemic debate. It is stated that in September 2014, the People's Representative Council (DPR) of the Republic

\footnotetext{
through the Constitutional Court which was filed by Lalu Ranggalawe on the $5^{\text {th }}$ of February, 2007. The Constitutional Court subsequently issued the Decree of the Constitutional Court Number 5/PUU-V/2007 which opens opportunities for independent candidates to run for regional head in the Pilkada held all over Indonesia.

4 Law Number 11 Year 2006 on Aceh Government [Article 67 Verse (1) letter d], concerning the accommodation of independent candidates is indivisible from the Memorandum of Understanding agreed upon by the Indonesian Government and the Free Aceh Movement which was signed on August the 15 ${ }^{\text {th }}, 2005$ in Helsinki, Finland.

5 See Treatise of the Constitutional Court Hearing Case Number 5/PUU-V/2007 Regarding the Judicial Review of Law No. 32 Year 2004 on Regional Government to the 1945 Constitution of the Republic of Indonesia.
} 
Table 1.

Comparison of Independent Candidate Regulations

\begin{tabular}{lllll}
\hline \multicolumn{1}{c}{ Regarding } & \multicolumn{1}{c}{ Law 12/2008 } & Law 1/2015 & Law 8/2015 & \multicolumn{1}{c}{ Law 10/2016 } \\
\hline Support requirement & $\begin{array}{l}\text { 3-6.5 percent of total } \\
\text { population }\end{array}$ & $\begin{array}{l}\text { 3-6.5 percent of total } \\
\text { population }\end{array}$ & $\begin{array}{l}\text { 6.5-10 percent of } \\
\text { total population }\end{array}$ & $\begin{array}{l}\text { 6.5-10 percent of } \\
\text { the final voters list } \\
\text { (DPT) }\end{array}$ \\
\hline $\begin{array}{l}\text { Amendment } \\
\text { suggestion }\end{array}$ & Constitutional Court & Government & DPR & $\begin{array}{l}\text { Constitutional } \\
\text { Court }\end{array}$ \\
\hline
\end{tabular}

Source: obtained through analysis of Indonesian laws and regulations

of Indonesia established Law No. 22 Year 2014 concerning the Election of Governors, Regents, and Mayors, as well as Law No. 23 Year 2014 concerning Regional Government. Both of these laws essentially contain substantive matters referring to regional head election through the Regional People's Representative Council (DPRD). The Draft Law (RUU) was initially suggested by the Minister for Internal Affairs to the DPR since 2012. However, in early October, President Susilo Bambang Yudhoyono issued two Governmental Regulations in Lieu of Law (Perppu), namely: Perppu No. 1 Year 2014 concerning Regional Head Election which replaces the electoral mechanism from indirect to direct election; and Perppu No. 2 concerning Regional Government which removes the DPRD authority to elect governors, regents, and mayors. These two regulations were issued following intense debates regarding which system is better, direct democracy or representative democracy, which ultimately ended in the government opting to directly involve the people. DPR finally issued Law No. 1 Year 2015 regarding the issuance of governmental regulation in lieu of law number 1 year 2014 concerning election of governors, regents, and mayors into becoming a law (Haryanto, 2014 a: 251). Law No. 1 Year 2015 was amended with the issuance of Law No. 8 Year 2015. Ultimately, provisions regarding independent candidates were amended with the publication of Law No. 10 Year 2016. ${ }^{6}$

\footnotetext{
6 This final stipulation was determined based on the result of judicial review filed to the Constitutional Court against Law No. 8 Year 20015.
}

Amendments in the regulation of independent candidates indicate that the political system in Indonesia remains highly influenced by interests of the elites and political parties. The substance in the presence of democracy can be likened to a pendulum which constantly moves in accordance to the interests of the elites and political parties. As a result, general election regulations continuously change without proper argumentation and eventually ends with the interference of the Constitutional Court. A comparison regarding amendments which have been made to the independent candidate regulations as of current has been summarized in Table 1 .

\section{Pilkada in South Sulawesi}

Pilkada has been conducted concurrently throughout 11 regencies in South Sulawesi on December the $9^{\text {th }}, 2015$. The elections were respectively held in Pangkep, Barru, Maros, Gowa, East Luwu, North Luwu, Tana Toraja, North Toraja, Selayar Islands, Soppeng, dan Bulukumba. Three of the regencies witnessed the participation of independent candidates, namely Pangkep which had two pairs of candidates, Gowa also had two pairs of candidates, and Bulukumba which had one pair of candidates. Of the five independent candidates, one pair succeeded in winning the election. Meanwhile, the other candidates did not show much of a fight as shown by the amount of votes they acquired (see Table 2).

The simultaneous Pilkada was conducted with the participation of 35 pairs of candidates in which 5 (14.29 percent) of them were 
Table 2.

Votes Cast for Independent Candidates in South Sulawesi 2015

\begin{tabular}{|c|c|c|c|c|}
\hline No. & Candidate Pair & Regency & Amount of Support & Votes Cast \\
\hline 1 & $\begin{array}{l}\text { Jumrana Salikki - } \\
\text { Husbiannas Alsi }\end{array}$ & Bulukumba & 47.932 & 16.096 Votes $(7.53 \%)$ \\
\hline 2 & $\begin{array}{l}\text { Djamaluddin Maknun - } \\
\text { Masykur }\end{array}$ & Gowa & 63.363 & 5.741 Votes $(1.58 \%)$ \\
\hline 3 & $\begin{array}{l}\text { Adnan Purichta Ichsan - } \\
\text { Abd Rauf Malaganni }\end{array}$ & Gowa & 70.953 & 151.373 Votes (41.65\%) \\
\hline 4 & $\begin{array}{l}\text { Sangkala H. Taepe - Andi } \\
\text { M. Ali Gaffar }\end{array}$ & Pangkep & 43.715 & 20.816 Votes $(11.53 \%)$ \\
\hline 5 & $\begin{array}{l}\text { Nur Achmad AS - Hafsul } \\
\text { W. Hafattah }\end{array}$ & Pangkep & 31.727 & 1.939 Votes $(1.7 \%)$ \\
\hline
\end{tabular}

Source: obtained through analysis of data from KPUs of Bulukumba, Gowa, and Pangkep.

independents. Actually, there was quite a lot of independent candidate pairs who registered to the General Election Commission (KPU) but they were declared ineligible to run. A few known examples are, in Bulukumba the Abdul Kahar Muslim-Muhammad Arif pair were not accepted as they did not submit their supporter signature sheets and documents; meanwhile, the Sukma Nurani Amperia-Abdul Hakim pair was unable to gather the minimum amount of supporter signature necessary; in Selayar, the only pair that registered as independents was the Andi Taufan Marimba-Andi Nur pair which was also unable to pass the administrative verification process; this was also the case in Soppeng in which the Andi Nurlinda-Muhammad Aksan pair did not pass verification; in Maros, there were two pairs of candidates that failed to pass, the Andi Ince Sari Said-Abdul Razak Labba pair and the Andi Anwar Banu-Andi Mappiasse pair, wherein both pairs were unable to fulfil the required amount of supporter signatures necessary. Of the 11 regencies, five of them, namely Barru, Tana Toraja, North Toraja, North Luwu, and East Luwu did not have any independent candidates registering to run.

In sum, as much as 13 pairs of regents and vice-regents candidates were registered through the independent track in 6 Regional KPUs throughout South Sulawesi in 2015. Although, ultimately there were only five pairs of candidates who participated in the election. The large number of minimum signature of supporters required became the main reason of failure in the verification process undertaken by the Regional KPU. Another significant issue was the level of determination candidate pairs had in organizing a campaign team which subsequently did not optimally execute the quite difficult task of collecting necessary documents in the form of identity card (KTP) and family register $(\mathrm{KK}){ }^{7}$ Running in the regional election through the independent track certainly does not see the need for any political dowry having to be paid to parties, yet it is undeniable that quite a substantial amount of funding support is necessary in order to maintain a campaign team working to collect supporters' documents (Haryanto, 2014a: 182). Ultimately, many registering independent candidates were unable to fulfil the requirements determined by KPU.

In the provisions of the KPU based on PKPU No. 9 Year 2015, it is stated that candidate pairs pursuing the independent track must undergo two stages of verification, which are administrative verification and factual verification. Administrative verification is the stage wherein the candidate pair submits document of support in the form of a support statement attached with a photocopy of resident identity (in softcopy and hardcopy) and a recapitulation of the amount of supports

\footnotetext{
7 Jayadi Nas (ex Chairman of South Sulawesi Province KPU), personal interview $19^{\text {th }}$ of September 2016.
} 
Table 3.

Candidate Pairs Registering as Independents in South Sulawesi 2015

\begin{tabular}{|c|c|c|c|c|}
\hline \multirow{2}{*}{ No. } & \multirow{2}{*}{ Name } & \multirow{2}{*}{ Regency } & \multicolumn{2}{|l|}{ Stages } \\
\hline & & & Verification 1 & Verification 2 \\
\hline 1 & $\begin{array}{l}\text { Hasan Hasyim - } \\
\text { Abdul Natsir }\end{array}$ & Gowa & $\begin{array}{l}\text { Minimum number of supporters was } \\
\text { not achieved }\end{array}$ & Failed \\
\hline 2 & $\begin{array}{l}\text { Abdul Kahar Muslim - } \\
\text { M. Arif }\end{array}$ & Bulukumba & $\begin{array}{l}\text { Did not submit softcopy and hardcopy } \\
\text { of supporters documents }\end{array}$ & Failed \\
\hline 3 & $\begin{array}{l}\text { Sukma Nurani Amperia - } \\
\text { Abdul Hakim }\end{array}$ & Bulukumba & $\begin{array}{l}31,399 \text { supporters documents did not } \\
\text { meet the required amount of } 36,978 \\
\text { supporters }\end{array}$ & Failed \\
\hline 4 & $\begin{array}{l}\text { Andi Taufan Marimba - Andi } \\
\text { Nur }\end{array}$ & Selayar & $\begin{array}{l}\text { Did not submit softcopy and hardcopy } \\
\text { of supporters documents }\end{array}$ & Failed \\
\hline 5 & $\begin{array}{l}\text { A. Nurlinda - Muhammad } \\
\text { Aksan }\end{array}$ & Soppeng & $\begin{array}{l}\text { Did not complete photocopy of } \\
\text { supporters documents }\end{array}$ & Failed \\
\hline 6 & $\begin{array}{l}\text { Andi Kaharuddin - Andi } \\
\text { Kastahar }\end{array}$ & Soppeng & 22,170 supporters documents & $\begin{array}{l}\text { Failed, only } 8,417 \text { of } \\
\text { factual supporters }\end{array}$ \\
\hline 7 & $\begin{array}{l}\text { Andi Ince Sari Said - Abdul } \\
\text { Razak Labba }\end{array}$ & Maros & $\begin{array}{l}\text { Minimum number of supporters was } \\
\text { not achieved }\end{array}$ & Failed \\
\hline 8 & $\begin{array}{l}\text { Andi Anwar Banu - } \\
\text { Andi Mappiasse }\end{array}$ & Maros & $\begin{array}{l}\text { Minimum number of supporters was } \\
\text { not achieved }\end{array}$ & Failed \\
\hline
\end{tabular}

Source: based on analysis of various sources.

acquired. In this stage, KPU verifies the documents by checking the minimum number of support and its distribution while also looking out for any double documents. As for the factual verification stage, it is conducted by the Regional KPU to validate direct support for the candidate pair on the field. A list of all candidate pairs that registered through the independent track in the 2015 South Sulawesi regional election and did not pass the verification stage is shown in Table 3.

Out of all the pairs of candidates participating in the South Sulawesi regional election, the Adnan Purichta Ichsan-Abdul Rauf Malaganni pair successfully won the election in the Gowa Regency. Meanwhile, the other independents were unable to do much-possibly lack determination-to win the election. For further elaboration, various analyses regarding the involvement of independent candidates in the concurrent election along with conclusions obtained from the occurring political events will be provided in the following section.

\section{Partly Independent}

Regarding the definition of individual (independent) candidates in the election system, the essence of this concept indicates that the said individual is unbound by a political party. This means that independent politicians are those that are nonpartisan and are not affiliated to any political party whatsoever. Nonetheless, the five pairs of independent candidates participating in the South Sulawesi concurrent election formed an interesting polarization. There was one candidate pair, Djamaluddin MaknumMasykur, who were indeed unaffiliated to any party, as both were senior bureaucrats of the regional administration. Meanwhile, Sangkala H. Taepe-Andi M. Ali Gaffar, the candidate pair in the Pangkep election, were both political party politicians from the National Mandate Party (Partai Amanat Nasional-PAN) and the Democratic Party (Partai Demokrat). Sangkala H. Taepe was a member of the South Sulawesi Province Regional People's Representative Council (DPRD) in the 2014-2019 period who subsequently resigned and ran for the election. As for the other three pairs of independent candidates, they are more aptly called partly independent. The Adnan Purichta IchsanAbdul Rauf Malaganni pair in the Gowa Regency represented a Golkar (Functional Group Party) politician with a bureaucrat. 
Table 4.

Profile of Independent Candidates in South Sulawesi 2015

\begin{tabular}{clll}
\hline No & \multicolumn{1}{c}{ Name } & \multicolumn{1}{c}{ Candidacy } & \multicolumn{1}{c}{ Profile } \\
\hline 1 & Jumrana Salikki & Regent of Bulukumba & Entrepreneur \\
2 & Husbiannas Alsi & Vice Regent of Bulukumba & Party Member \\
3 & Djamaluddin Maknun & Regent of Gowa & Bureaucrat \\
4 & Masykur & Vice Regent of Gowa & Bureaucrat \\
5 & Adnan Purichta Ichsan & Regent of Gowa & Party Member \\
6 & Abd Rauf Malaganni & Vice Regent of Gowa & Bureaucrat \\
7 & Sangkala H. Taepe & Regent of Pangkep & Party Member \\
8 & Andi M. Ali Gaffar & Vice Regent of Pangkep & Party Member \\
9 & Nur Achmad AS & Regent of Pangkep & Entrepreneur \\
10 & Hafsul W. Hafattah & Vice Regent of Pangkep & Party Member \\
\hline
\end{tabular}

Source: based on analysis of various sources.

The Jumrana Salikki-Husbiannas Alsi pair in the Bulukumba Regency was a pairing of an entrepreneur and a politician of the Democratic Party. Another pair from the Pangkep Regency, Nur Achmad AS-Hafsul W. Hafattah was a combination of an entrepreneur and a politician from the United Development Party (PPP).

By reason of strategy, independent politicians are consequently more convinced to choose a party politician as a pairing candidate for the regional election. This also applies mutually, as the choice of party politicians pairing up with entrepreneurs or bureaucrats is based on political strategy. For instance, in the Pangkep Regency, Nur Achmad AS who is an entrepreneur chose Hafsul W. Hafattah who is a cadre of the United Development Party. Nur Achmad's choice was based on two reasons. ${ }^{8}$ Firstly, Hafsul W. Hafattah's experience in the world of politics is considered to be able to assist him in having more seasoned political strategies within their team. Secondly, choosing Hafsul W. Hafattah meant the candidate pair would be able to represent the geopolitics of Pangkep, namely the constituents in the mainland and those in the islands.

Meanwhile, in the Bulukumba Regency, Jumrana Salikki an entrepreneur decided to

\footnotetext{
8 NA, personal interview $3^{\text {rd }}$ of October 2016.
}

choose Husbiannas Alsi, a Democratic Party politician. Having little experience in politics and the fact that he mostly stayed in Jakarta became Jumrana Salikki's main reasons to pair up with a seasoned party politician in Bulukumba. ${ }^{9}$ This option is regarded as appropriate, keeping in mind that Husbiannas Alsi was seated as the Vice Chair of Bulukumba DPRD for the 2009-2014 period. One of the significant capital this pair had in order to procure votes from the electorates is the abundance of economic capital Jumrana Salikki has, while on the socio-cultural capital side they were deemed to be uninfluential. Jumrana Salikki well realized the tremendous expense he had to spend to gain the people's sympathy and support. ${ }^{10}$

In short, half of the political actors mentioned in the South Sulawesi regional election were party functionaries, while the other half were entrepreneurs and bureaucrats (see Table 4). There was no true independent (nonpartisan) during the concurrent regional election in South Sulawesi. The political actors involved were those who have had long experiences in political parties although a number of the independent candidates did indeed come from outside of existing parties. In

\footnotetext{
9 JS, personal interview $5^{\text {th }}$ of September 2016

${ }^{10} \mathrm{JS}$, personal interview $5^{\text {th }}$ of September 2016
} 
the end, the polarization above shows that local political elites remain to be dominated by party cadres, entrepreneurs, and bureaucrats.

\section{Exit Strategy}

The polarization of independent candidates in South Sulawesi shows that half of the 10 candidates for regent and vice-regent were political party functionaries. There was even a candidate pair in the Pangkep Regency in which both candidates were party activists. Three of the candidates chose to pair up with nonpartisans. Party activists running through the independent track is indeed a phenomenon found in most parts of the Indonesian regions. At the national level, many independent candidates who contested in the concurrent regional election in 2015 were party politicians in which the option of becoming an independent candidate serves as an exit strategy for party members who can no longer advance through the political party track (Sugiarto, 2016). This seems to also be the case during the concurrent election in South Sulawesi.

As mentioned earlier, Sangkala H. TaepeAndi M. Ali Gaffar, the independent candidates in the Pangkep regional election were party functionaries who were unable to utilize the party to run in the election. Although, Sangkala H. Taepe was actually included as a considerable party cadre due to his position as a member of the South Sulawesi Province DPRD for the 2014-2019 period from the National Mandate Party fraction. Yet during the Pangkep regional election, a number of parties preferred two other candidates, wherein the National Awakening Party (PKB) and Gerindra Party (with 4 seats respectively) had supported the Abd. Rahman Assagaf-Kamrussamad pair, while the Democratic Party, the Indonesian Democratic Party of Struggle (PDIP), the Prosperous Justice Party (PKS), and the Hanura Party (with 4, 2, 2, and 1 seat respectively) supported the Syamsuddin A. Hamid-Syahban Sammana pair. As for the National Mandate
Party (PAN), the Golkar Party, and the United Development Party (PPP) (with 2, 10, and 5 seats respectively), they did not support any candidates. While, in fact, the requirement to support a candidate pair in this regency is merely 7 seats. The head of the Sangkala H. Taepe-Andi M. Ali Gaffar campaign team confirmed that they could not afford the political dowry needed for the party that will support them. ${ }^{11}$ Another possibility is that the Sangkala H. Taepe-Andi M. Ali Gaffar team was found to be unappealing to the parties due to their low level of electability. Hence, it was the most rational choice for the pair to opt for the independent track.

This is also the case regarding the decision made by Adnan Purichta Ichsan Yasin Limpo to advance through the independent track in the Gowa regional election. His choice to take the independent track instead of going through the party was indeed interesting. In reality, Adnan Purichta Ichsan Yasin Limpo has a strong influence over political parties in Gowa such as the Golkar Party, PAN, and Gerindra through his familial networks. ${ }^{12}$ Adnan himself was a member of the South Sulawesi DPRD for two periods. However, as the regional election approached, none of the political parties joined forces to support Adnan. The lack of party support towards Adnan's candidacy is due to a regulation regarding political dynasty which did not allow political family to advance in the general election if one of their family members was seated as a regional head in the previous period. Being the son of Ichsan Yasin Limpo, the then active Regent of Gowa, no political party decided to support Adnan's candidacy. Although, subsequently Adnan succeeded in filing a claim to the Constitutional Court.

\footnotetext{
${ }^{11}$ MAF, personal interview, $25^{\text {th }}$ of September 2016

12 Several members of the Yasin Limpo family are functionaries of political parties, among others, Ichsan Yasin Limpo, Tenri Olle Yasin Limpo, and Haris Yasin Limpo in the Golkar Party, Dewi Yasin Limpo in the Hanura Party, Thita Syahrul Yasin Limpo in PAN, and Andi Pahlevi in the Gerindra Party.
} 
The result of the Constitutional Court hearing dropped the article prohibiting participation of political family, and Adnan was subsequently able to run as a candidate in the Gowa regional election.

Ichsan Yasin Limpo who is Adnan's father and political advisor said that Adnan's candidacy as an independent was an anticipatory step as no party were in their favor and it was also undertaken for political imagery in order to gain the public's trust. ${ }^{13}$ Although, in the end, once Adnan was verified as an independent candidate along with his running mate Abdul Rauf Malaganni, the parties of PDIP, PAN, and Gerindra had subsequently acknowledged their support for the pair. These parties then formed a coalition of political parties supporting the independent candidates (Antara Sulsel, 2015).

\section{Affordable Price}

In the provisions of Law No. 8 Year 2015 article 40 verse 1 , it is stated that in order to register as a candidate pair through a political party one must fulfil the requirement of acquiring at least 20 percent support from the total number of seats in the Regional People's Representative Council (DPRD). For instance, the Gowa Regency which has a total of 45 seats requires a candidate pair to acquire support from a minimum of 9 seats from the DPRD. According to one of the independent candidates from Gowa, this requisite was deemed too "costly". ${ }^{14}$ He elaborated that when his name was popularly talked about to run in the Gowa regional election, a politician approached him and offered the party to support his candidacy with the requirement of paying a "political dowry" in the sum of 500 million rupiahs per seat. This meant he must at least prepare a fund of 4.5 billion rupiahs to acquire support for his candidacy through the political party.

\footnotetext{
${ }^{13}$ Mattewakkan (political researcher for the Yasin Limpo family), personal interview $6^{\text {th }}$ of October 2016.

${ }^{14} \mathrm{DM}$, personal interview $21^{\text {st }}$ of September 2016.
}

This political dowry is regarded as difficult to fulfil for this candidate who was head of the agricultural services at the time.

Similar to the above case, the independent pair of Nur Achmad AS-Hafsul W. Hafattah in the Pangkep Regency based their involvement in Pilkada through the independent track on the small amount of cost they had to spend. They claimed to have spent only 30 million rupiahs for operational expenses of collecting ID cards. According to Nur Achmad, the price for one seat was approximately 500 million to 1 billion rupiahs. ${ }^{15}$ The exorbitant cost of dowry led the independent track to become the most rational alternative choice for them. This means that in order to run in the regional election, an independent does not need to spend a substantial budget in comparison to the party track.

The independent track is regarded as the affordable choice compared to the option of allying with political parties. Utilizing the party is a costly option full of intricacies. As an example is the case which occurred in the Soppeng Regency wherein one of the candidates had to compete with another to obtain the blessings of the Central Executive Board (DPP) of one of the parties in Jakarta. The interview result obtained from a reliable source states that one of the candidates who had acquired consent from the party had to reaccept the fund that he had initially transferred to the party. The candidate had in fact transferred a sum of 8 billion rupiahs. It is assumed that his political rival had paid a bigger sum of political dowry. ${ }^{16}$

\section{Strong Personal Capital}

Out of all the independent candidates in the 2015 South Sulawesi regional election, only Adnan Purichta Ichsan Yasin Limpo-

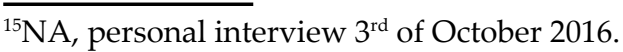

${ }^{16} \mathrm{AHS}$ (political consultant and researcher in the Soppeng Pilkada), personal interview $19^{\text {th }}$ of October 2016.
} 
Abdul Rauf Malaganni were able to win the race. The key factor to their victory lies in the political strength Adnan Purichta Ichsan Yasin Limpo yielded as a member of the Yasin Limpo clan, a family of rulers in the Gowa Regency. ${ }^{17}$ Although Adnan Purichta Ichsan Yasin Limpo's experience in politics is indeed no less formidable, with a history of being a member of the South Sulawesi DPRD for two periods from two different parties, The Democratic Party and Golkar. Even so, his political seats were obtained from the personal strength of his family who at the time was in power of the government and capable of influencing the people's political choices.

Analyzing the personal strength of Adnan Purichta Ichsan Yasin Limpo will lead to the presence of a political clan or dynasty. Michael Buehler (2013) summarized that the main reason contributing to the success of the Limpo clan is heritage. Chronologically speaking, his personal strength has been established since the not too distant past. It is said that Yasin Limpo, Adnan's grandfather, who was born in 1935 started his professional career in the military. Once he ended his military career, he held various government positions, namely as Acting Regent of Gowa, Luwu, Majene, and Maros, although it was only for a short period. Yasin Limpo had even become the Acting Governor of South Sulawesi in the 1960s. ${ }^{18}$ Yasin Limpo also became highly influential in the Golkar Party and he utilized

\footnotetext{
${ }_{17}$ Adnan's uncle and father were consecutively the Regent of Gowa from 1994 to 2015. For a complete summary on this political family, see Michael Buehler (2013) "Married with Children: The second round of direct elections for governors and district heads shows that democratisation is allowing powerful families to entrench themselves in local politics". Inside Indonesia, 112.

${ }^{18}$ There was a transitional period at the time of the Sulawesi Province being divided into North and South Sulawesi Provinces. As a result, there was a vacancy in the governor's seat for eight months, from April 20, 1960 until December 13, 1960. During the eight-month period, Yasin Limpo was tasked as the Acting Governor (Mattewakkan, 2016: 68).
}

his connections to establish his businesses. According to Buehler (2013), Yasin Limpo used the military units under his command to acquisition land in Gowa. In the end, this family has quite a significant amount of land. As of current, several businesspersons in the extractive industry of division $\mathrm{C}$ mining such as gravel and sand quarries along the Jeneberang river are this clan's trusted individuals. ${ }^{19}$ Heritages of social and economic capital serve as the personal strength of Adnan which secured his victory as an independent.

The continuity of the Yasin Limpo clan's authority that has been overpowering the Gowa Regency for several decades is the answer to how strong the influence of personal figure has compared to political parties in this region. As a descendant of the Yasin Limpo clan, Adnan himself saw no use of any party to win the political contestation. The existing political parties were mere attributes, aside from being means of political pragmatism for its regional organizers. In this case, the party only served as an entry point to becoming a candidate, not the determinant of victory in pilkada. Adnan's victory demonstrates that he certainly did not need the party, as he held government authority through his father's position as the Regent of Gowa and his uncle as the Governor of South Sulawesi. Additionally, his family yields great authority over natural resources in the region.

\section{Comparing Independent Candidates in Indonesia}

As a national comparison, independents competing in the concurrent regional election of 2015 totaled 35 percent which amounted to 156 pairs of candidates. Of that amount, 77.8 percent were in regions that had a Final Voters List (DPT) under 500,000 people. While 22.2 percent were in regions with a number of

\footnotetext{
${ }^{19}$ Mattewakkan (political researcher for Yasin Limpo' family), personal interview $6^{\text {th }}$ of October 2016.
} 
voters over 500,000. Out of the total registered independents, 14.4 percent claimed victory which was five pairs positioned as mayors/vicemayors and eight pairs positioned as regents/ vice-regents. The victory of these independents can be analyzed throughout the regions in Indonesia bearing the following results: independent candidates with the most win were found in the East Nusa Tenggara island (33.3 percent) and Kalimantan (22.2 percent); while in West Nusa Tenggara and Maluku, no independent candidate won; independents winning in municipal administrative regions (cities) was 31.3 percent while in regional administrative regions (regencies) was 11.0 percent. ${ }^{20}$ In the 2015 concurrent regional election as a whole, five pairs of candidates were elected and able to secure the position of mayor/vice-mayor, while eight pairs of candidates were elected to become regents/ vice-regents.

At the provincial level, out of the seven regions conducting elections, the candidates for governor and vice-governor were all proposed by political parties and none had contested through the independent track. Aside from the consideration of the high level of requirements for independents in the regional election, there are other considerations such as prevailing regulation regarding the decision making process which must involve political parties at the Provincial DPRD as well as the high level of political fragmentation in the parliament which discourages independent candidates to register (Pratama and Maharddhika, 2016: 24). In the province case, it seems that political party coalition has a major role in the candidacy of governor and vice-governor in the 2015 concurrent regional election. The option to run as an independent is indeed a heavy burden. Having to collect a minimum requirement of ID cards totaling 6.5-10 percent of the DPT is

\footnotetext{
${ }^{20}$ Summarized from the Research Report on the 2015 Concurrent Election Results, Skala Survei Indonesia (SSI).
}

considered difficult to achieve. As an example, to become an independent candidate in the South Sulawesi gubernatorial election, one must at a minimum prepare 7.5 percent of support from 6,293,477 DPTs or have at least collected 472,011 ID cards for support. This is undoubtedly a very daunting amount.

\section{Lessons from Independent Candidate Cases}

Several practitioners and scholars state that the advent of independent candidates in the Indonesian election system is a means for the rise of alternative leaders outside of political parties, it is also regarded as beneficial to political participation as well as to efforts in consolidating democracy (Rosari, 2015; Susetyo, 2016). Distrust towards corrupt and pragmatic political parties is the reason. Another argument states that the independent candidate model can maintain and keep the people's trust hence enabling service and defense of public interests. In turn, this will lead to decrease in corruption and increase in people's political participation. Yet, what had occurred in the South Sulawesi concurrent regional election was far from the above mentioned rationale. That being said, what are the lessons learned from the case of the South Sulawesi concurrent regional election? Firstly, the political reality practiced in Pilkada was merely an event of economic negotiations for political parties in the regions. The sale and purchase of seats for candidates are common occurrences. The phrase "political dowry" has become a term signifying the requirement of party support to a candidate through a sum of money. In turn, running as independents is the sensible option as it is inexpensive.

Secondly, the independent candidates involved in the South Sulawesi concurrent regional election were not really independent. Half of the independents were political party functionaries who had chosen the independent track as their political exit strategy. Their main reason was their incapability of paying political 
dowry. Meanwhile, nonpartisan independents, did not truly represent the community with issues of alternative politics. One of them was only present to sustain the family clan's grasp as heir to the throne. This was also the case in two Kalimantan regions wherein a wife and child chose the independent track to replace the husband and father.

Thirdly, as of the 2015 concurrent regional election, the majority of participants in the regional election was dominated by party cadres, entrepreneurs, and bureaucrats. As a comparison, when regional election was initially conducted in 2005 up till 2013, the majority of running candidates were bureaucrats, followed by entrepreneurs with business interests tied to the government such as construction company, and lastly party cadres (Buehler, 2013). The occurring polarization actually remains the same, both through the party track or the independent one. This means that there is nothing new in the practice of local democracy, regarding its actors and strategies.

Fourthly, choosing the independent track is a form of self confidence of local politicians who are truly certain with the political capital one yields. The main capital being the power of character in the form of popularity and the power of political family clan. As found in South Sulawesi and even in many other regions throughout Indonesia, the case in which political clans rule over public positions in the regions which are subsequently inherited by their heirs is a factual and unceasing phenomenon (Haryanto, 2014a). When a political clan wields power and becomes a regime, personal power becomes an instrument of democracy which then considers political parties as mere attributes.

Lastly, is the conclusion which states that personal power is becoming more influential in winning political contestation with the advent of direct election of regional leaders (Buehler, 2009) which has found its turning point in the 2015 concurrent regional election in South Sulawesi. This can be observed by the small number of independent candidates who registered. Even more so at the provincial level, in which there was no independent candidate at all. Therefore, this research concludes that political parties still have their appeal to regional head candidates as a political power in regional elections. This is in line with our previous research on the rise of party identification in the South Sulawesi regional election of 2013 (Haryanto, 2014b). Although, there was one independent candidate in the 2015 regional election who succeeded in winning the election by using the power of political clan which has been conquering the region for two decades. Nevertheless, most of the independent candidates involved in the regional election were proven to have failed in mobilizing their personal power.

\section{Conclusion}

The most straightforward definition for an independent candidate is an unaffiliated politician to any political party. However, this definition only applies within the perspective of an election system or according to the inference of the general election commission. An independent which is essentially meant to rival party domination and to become an alternative option in the election process remains to be scrutinized. The independent track in Indonesia is merely one of the means other than the party to pursue political position in the regions. Independent candidates do not undertake a process to enhance democracy by offering a different ideology that is unbounded in any way by what political parties has employed thus far.

Independent candidates in Indonesian local politics can be categorized to be in pursuit of office/position. There is no clear basis as to what they are advocating for. They are merely politicians who remain unfortunate and incompatible in their dealings with political parties, they are relatively 
underprivileged or poor, and pragmatic. Reflecting on the South Sulawesi experience, there is yet to be an independent who is truly a social activist wanting to promote alternative issues, a representative of interest groups, or a representative of classes in the local community. Independent candidates are no different to party candidates, the issues and political product they advocate are the same. In short, independents are a part of the Schumpeterian procedural rationality for mere circulation of political elites. There is nothing new and rejuvenating in the practices of local democracy in Indonesia.

\section{References}

Antara Sulsel. (2015). Parpol Koalisi Adnan-Kio Bentuk Tim Pemenangan. Retrieved October 8, 2016, from http://www.antarasulsel.com/ berita/66984/parpol-koalisi-adnan-kiobentuk-tim-pemenangan.

Arbas, Cakra, Husni J., \& Suhaidi. (2015). Independent Candidate in Regional Head Election in Indonesia. Journal of Law, Policy and Globalization. 35, 159-164.

Bolleyer, N., Liam W. (2009). The Puzzle of Non-Party Actors in Party Democracy: Independents in Ireland. Comparative European Politics, 7(3), 299-324.

Brancati, D. (2008). Winning Alone: The Electoral Fate of Independent Candidates Worldwide. The Journal of Politics, 70(3), 648-662.

Buehler, M. (2009). The Rising Importance of Personal Networks In Indonesian Local Politics: An Analysis of District Government Head Elections in South Sulawesi in 2005 M. Erb \& P. Sulistiyanto (eds) Deepening Democracy in Indonesia? Direct Elections for Local Leaders (Pilkada). Singapore: ISEAS Publishing.

Buehler, M. (2013). Married with Children: The Second Round of Direct Elections for Governors and District Heads Shows that Democratisation is Allowing Powerful Families to Entrench Themselves in Local Politics. Inside Indonesia, 112. Retrieved from http://www. insideindonesia.org/married-with-children.

Costar, B. J., Jennifer C. (2004). Rebels with a Cause: Independents in Australian Politics. Sydney: UNSW Press.

Ehin, P., Mihkel S. (2012). Party Voters Gone Astray: Explaining Independent Candidate Success in the 2009 European Elections in Estonia. Journal of Elections, Public Opinion and Parties, 22(3), 269-291. Hale, H. (2007). Why not Parties in Russia?: Democracy, Federalism, and the State. Cambridge: Cambridge University Press.

Haryanto. (2014a). Klanisasi Demokrasi: Politik Klan Qahhar Mudzakkar di Sulawesi Selatan. Yogyakarta: POLGOV.

Haryanto. (2014b). Kebangkitan Party ID: Analisis Perilaku Memilih dalam Politik Lokal di Indonesia. Jurnal Ilmu Sosial dan Ilmu Politik, 17(3), 295-313.

Ishiyama, John, Anna B., \& Angela S. (2011). Political Parties, Independents and the Electoral Market in Sub-saharan Africa. Party Politics, 19(5), 695-712.

Junzhi, H. (2010). Independent Candidates in China's Local People's Congresses: A Typology. Journal of Contemporary China, 19(64), 311-333.

Keputusan Mahkamah Konstitusi Nomor 5/ PUU-V/2007.

KPU. (2015, October 8). Hasil Pemilihan. Retrieved from http://infopilkada.kpu.go.id/ sitap-2015/index.php?r=hasilpemilihan/ adminex.

Law No $1 / 2015$

Law No 10/2016

Law No 12/2008

Law No 8/2015

Martini, N. P. E., Ibrahim. (2013). Problematika Calon Independen dalam Pemilihan Umum Kepala Daerah. Kertha Semaya, 01(03), 1-14.

Mattewakkan. (2016). Konflik Internal Keluarga Yasin Limpo dalam Pilkada Gowa 2015. 
Unpublished Magister thesis, Makassar: Universitas Hasanuddin.

Moser, R. (1999). Independents and Party Formation: Elite Partisanship as an Intervening Variable in Russian Politics. Comparative Politics, 31(2), 147-165.

Nuryanti, S. (2015). Intervensi Penyelenggaraan Pemilukada: Regulasi, Sumberdaya dan Eksekusi. Jurnal Ilmu Sosial dan Ilmu Politik, 19(2), 125-140.

PKPU (Peraturan Komisi Pemilihan Umum) No. 9 Year 2015.

Pratama, H. M., Maharddhika, (2016). Prospek Pemerintahan Hasil Pilkada Serentak 2015. Jakarta: Yayasan Perludem.

Rosari, Maria. (2015, September 9). Calon Independen Untuk Demokrasi Indonesia.
Retrieved from http://babel.antaranews. com/berita/24783/calon-independen-untukdemokrasi-indonesia.

Schaffner, Brain F., Matthew J. Streb, \& Gerald C. W. (2001). Teams without Uniforms: The Nonpartisan Ballot in State and Local Elections. Political Research Quarterly 54(1), 7-30.

Sugiarto, Toto. (2016, April 30). Menjadikan Pilkada Menarik dan Bermutu. Kompas, 6.

Susetyo, Benny. (2016, March 21). Gagal Membaca Zaman. Kompas, 7.

Weeks, Liam. (2008). We don't like (to) party: explaining the significance of Independents in Irish political life. Unpublished dissertation, University of Dublin, Trinity College. 